\title{
Benefits of the Mixtures of Ionic Liquid and Organic Electrolytes for Sodium-ion Batteries
}

\section{$\operatorname{AUTHOR}(S):$}

Hwang, Jinkwang; Yang, Huan; Matsumoto, Kazuhiko; Hagiwara, Rika

\section{CITATION:}

Hwang, Jinkwang ...[et al]. Benefits of the Mixtures of Ionic Liquid and Organic Electrolytes for Sodium-ion Batteries. Journal of The Electrochemical Society 2021, 168(3): 030508.

\section{ISSUE DATE:}

2021-03

URL:

http://hdl.handle.net/2433/265327

\section{RIGHT:}

This is the Accepted Manuscript version of an article accepted for publication in Journal of The Electrochemical Society. The Electrochemical Society and IOP Publishing Ltd are not responsible for any errors or omissions in this version of the manuscript or any version derived from it. The Version of Record is available online at https://doi.org/10.1149/19457111/abe8bb.; This is not the published version. Please cite only the published version.この論文は出版社版でありませ ん。引用の際には出版社版をご確認ざ利用ください。 


\title{
Benefits of the Mixtures of Ionic Liquid and Organic Electrolytes for Sodium-ion Batteries
}

Jinkwang Hwang, ${ }^{1}$ Huan Yang, ${ }^{1}$ Kazuhiko Matsumoto, ${ }^{1,2,{ }^{*}, z}$ Rika Hagiwara ${ }^{1,2, *}$

\author{
${ }^{I}$ Graduate School of Energy Science, Kyoto University, Sakyo-ku, Kyoto 606-8501, Japan \\ ${ }^{2}$ Unit of Elements Strategy Initiative for Catalysts \& Batteries (ESICB), Kyoto University, \\ Katsura, Kyoto 615-8510, Japan \\ *Electrochemical Society Member. \\ Corresponding author: Kazuhiko Matsumoto \\ ZE-mail:k-matsumoto@energy.kyoto-u.ac.jp
}

The contents of this paper were presented at PRiME2020 as A04-0817. 


\begin{abstract}
The successful commercialization of sodium-ion batteries is heavily contingent on the development of suitable electrolytes marked with economic feasibility and stable electronic performance. To this end, we present a group of hybrid electrolytes made from the $\left[\mathrm{C}_{3} \mathrm{C}_{1}\right.$ pyrr $][\mathrm{FSA}] \quad\left(\mathrm{C}_{3} \mathrm{C}_{1}\right.$ pyrr $=N$-methyl- $N$-propylpyrrolidinium $)$ ionic liquid (IL) and propylene carbonate organic liquid (OL) electrolytes with $\mathrm{Na}[\mathrm{FSA}]$ (FSA = bis(fluorosulfonyl)amide) and $\mathrm{Na}\left[\mathrm{ClO}_{4}\right]$ salts are mixed with exploring the possibilities of cost reduction, high performance and inhibited flammability. The thermal stability tests reveal that the addition of IL can effectively suppress flammability. Herein, the physicochemical and electrochemical properties of the various mixing ratios of the aforementioned hybrid electrolytes (ILOL) are investigated for sodium-ion batteries. Furthermore, full cell tests using hard carbon negative and $\mathrm{NaCrO}_{2}$ positive electrodes using the ILOL systems improve electrochemical performance and enable battery operation at $363 \mathrm{~K}$.
\end{abstract}

Keywords: sodium-ion batteries; electrolytes; organic solvents; ionic liquids 


\section{Introduction}

The shift towards energy sustainability has captivated interest in sodium-ion batteries (SIBs) as large-scale energy storage devices due to the great abundance and low cost of sodium resources. ${ }^{1-4}$ The advancement of these battery systems is contingent on the development of efficacious electrolytes in order to optimize critical parameters such as their electrochemical stability, performance, safety, as well as their economic feasibility. ${ }^{5-9}$ In SIB performance measurements, organic electrolytes derived from $\mathrm{Na}$ salts such as $\mathrm{Na}\left[\mathrm{ClO}_{4}\right]$ or $\mathrm{Na}\left[\mathrm{PF}_{6}\right]$ along with EC (ethylene carbonate)-based organic carbonates, PC (propylene carbonate), DMC (dimethyl carbonate), and DEC (diethyl carbonate) have gained widespread utility in an attempt to emulate the performance of their well-established lithium analogs utilized in lithium-ion batteries (LIBs). ${ }^{7,10-13}$ However, the resultant solid electrolyte interphase (SEI) layers comprising $\mathrm{Na}^{+}$ions tend to be inhomogeneous and fragile, delivering lower stability than those formed with $\mathrm{Li}^{+}$ions. ${ }^{5,9}$ Moreover, organic electrolytes have been found to be highly flammable and volatile, making them susceptible to fire hazards and reliability issues. ${ }^{14-17}$

It is in this light that ionic liquid electrolytes have emerged as safe alternatives on account of their high thermal stabilities characterized by low flammability, negligible volatility, and a wide electrochemical window. ${ }^{14,15,18-20}$ Furthermore, ionic liquid have been reported to facilitate the formation of stable and highly conductive SEI layers, presenting the possibility of similar or in some cases superior electrochemical performance compared to organic electrolytes. ${ }^{7}$ By the same token, the high thermal stability enables ionic liquid electrolytes to facilitate intermediate-temperature battery operations which not only confer the prospects of repurposing ubiquitous waste heat from day-to-day activities, industrial processes and the residual heat from battery operations but also the possibility of improved performance. ${ }^{10} \mathrm{In}$ fact, previous studies have reported remarkable improvements in the electrochemical performance of bis(fluorosulfonyl)amide (FSA)-based ionic liquid electrolytes at intermediate 
temperatures. ${ }^{15,19,21-28}$

Despite the massive advantages of enhanced safety and the prospects of improved performance, the high costs of ionic liquids heavily inhibit their successful deployment in battery technologies with the aim of SIB commercialization. This has prompted the exploration of hybrid electrolyte systems comprising mixtures of ionic liquid and organic electrolytes for use in both LIBs ${ }^{29-34}$ and SIBs. ${ }^{35-37}$ In an early study on hybrid electrolytes, the addition of a [1ethyl-3-methylimidazolium][bis(trifluoromethylsulfonyl)amide] ionic liquid into ethylene carbonate (EC) and diethyl carbonate (DEC) organic electrolytes, evinced suppressed flammability and volatility in the resultant electrolytes. ${ }^{29}$ Subsequent studies revealed have also indicated improved electrochemical performance as a result of superior interfacial properties, such as less resistive SEI layers formed upon addition of ionic liquid into organic electrolytes. ${ }^{30,37}$ Nonetheless, such studies are still at their early stages as the innate electrochemical performance of the positive and negative electrodes in the hybrid electrolytes cannot be assessed using half-cell configuration measurements. For half-cell tests utilizing these electrolytes, electrochemical performance is significantly influenced by the high reactivity between the lithium or sodium metal counter electrodes and the hybrid electrolytes, causing excessive consumption of the metal counter electrodes. ${ }^{21}$ Thus, it is difficult to envision the wholesome performance of such systems with the use of full cell configurations alone.

In this study, a $\left[\mathrm{C}_{3} \mathrm{C}_{1}\right.$ pyrr][FSA $]\left(\mathrm{C}_{3} \mathrm{C}_{1} \text { pyrr }^{+}=N \text {-methyl- } N \text {-propylpyrrolidinium }\right)^{17}$ ionic liquid (IL) along with $\mathrm{Na}[\mathrm{FSA}]$ and $\mathrm{Na}\left[\mathrm{ClO}_{4}\right]$ salts and a $\mathrm{PC}$ organic liquid solvent (OL) are mixed to form a hybrid electrolyte system (hereafter called ILOL). The physical and electrochemical properties are explored at the various mixing ratio of the ILOL systems for SIBs. The practical electrochemical properties are evaluated through full cell cycle tests using hard carbon (HC) negative electrodes and layered O3-type $\mathrm{NaCrO}_{2}(\mathrm{NCO})$ positive electrodes. 


\section{Experimental}

Materials. - All the samples, including salts, the organic solvent, electrode materials, electrolytes, and cells, were handled and prepared in an Ar-filled glove box $\left(\mathrm{H}_{2} \mathrm{O}<1 \mathrm{ppm}\right.$ and $\mathrm{O}_{2}<1 \mathrm{ppm}$ ). The salts; $\mathrm{Na}$ [FSA] (Mitsubishi Materials Electronic Chemicals, purity $>99 \%$ ), $\left[\mathrm{C}_{3} \mathrm{C}_{1}\right.$ pyrr][FSA] (Kanto Chemical, purity $>99.9 \%$ ), $\mathrm{NaClO}_{4}$ (Fujifilm Wako Pure Chemical Industries, purity $>95.0 \%$ ) were dried under vacuum for $24 \mathrm{~h}$ at $353 \mathrm{~K}$. The battery-grade PC solvent (Kishida Chemical) and $\mathrm{Na}\left[\mathrm{ClO}_{4}\right]-\mathrm{PC}$ solution $\left(1 \mathrm{~mol} \mathrm{dm}^{-3}\right.$, Kishida Chemical) were used as purchased.

Electrolytes. - Table 1 lists the ILOL systems and the reference electrolytes prepared in this study. The $1 \mathrm{~mol} \mathrm{dm}^{-3} \mathrm{Na}[\mathrm{FSA}]-\left[\mathrm{C}_{3} \mathrm{C}_{1}\right.$ pyrr][FSA] and $1 \mathrm{~mol} \mathrm{dm}^{-3} \mathrm{Na}\left[\mathrm{ClO}_{4}\right]-\mathrm{PC}$ electrolytes were mixed in the target ratios and stirred for $1 \mathrm{~h}$ for the ILOL systems. The reference electrolytes namely, $1 \mathrm{~mol} \mathrm{dm}{ }^{-3} \mathrm{Na}[\mathrm{FSA}]-\mathrm{PC}, 1 \mathrm{~mol} \mathrm{dm}^{-3} \mathrm{Na}\left[\mathrm{ClO}_{4}+\mathrm{FSA}\right]-\mathrm{PC}(0.5 \mathrm{~mol}$ $\mathrm{NaClO}_{4}+0.5 \mathrm{~mol} \mathrm{Na}[\mathrm{FSA}]$ in $1 \mathrm{dm}^{3}$ solution), and $1 \mathrm{~mol} \mathrm{dm}^{-3} \mathrm{Na}[\mathrm{FSA}]-\left[\mathrm{C}_{3} \mathrm{C}_{1}\right.$ pyrr] [FSA] $+\mathrm{PC}$ $(5: 5, \mathrm{v}: \mathrm{v})$ were prepared by mixing the corresponding salts and solvent in the target ratios using a volumetric flask. The prepared electrolytes were impregnated into a glass filter separator (Whatman GF/D). The typical water content of the ILOL systems was below $20 \mathrm{ppm}$, in accordance with Karl-Fischer titration (899 Coulometer, Metrohm).

Electrode and cell preparations. - The NCO positive electrode material was prepared via a solid-state reaction between $\mathrm{Na}_{2} \mathrm{CO}_{3}$ and $\mathrm{Cr}_{2} \mathrm{O}_{3}$ at $1123 \mathrm{~K}$ for $5 \mathrm{~h}$, as previously reported. ${ }^{38} \mathrm{The}$ HC negative electrode material was used as purchased (CARBOTRON P, Kureha Battery Materials Japan Co., Ltd.). The positive electrode slurry was prepared by mixing NCO, acetylene black, and PVDF (75:15:10 in wt\%) in $N$-methylpyrrolidone, whereas the negative electrode slurry was prepared by mixing HC, acetylene black, and PVDF in (85:5:10 in wt\%) 
in $N$-methylpyrrolidone using a planetary mixer (AR-100, Thinky, Tokyo, Japan). The resulting slurry was pasted on an $\mathrm{Al}$ foil. The $\mathrm{NCO}$ positive and $\mathrm{HC}$ negative electrodes were dried under vacuum at $353 \mathrm{~K}$ for $12 \mathrm{~h}$. The loading mass of active materials in the positive and negative electrodes were approximately 3 and $1 \mathrm{mg}$-active material $\mathrm{cm}^{-2}$, respectively, after the drying process. The weight ratio of active materials in the positive and negative electrodes was adjusted to $3.0: 1.0$, which corresponds to the capacity ratio of $1.2: 1.0=Q_{\text {Positive electrode }}$ : $Q_{\text {Negative electrode }}(Q$ denotes practical capacity) based on the practical capacities of NCO (100 $\left.\mathrm{mAh} \mathrm{g}^{-1}\right)$ and $\mathrm{HC}\left(250 \mathrm{mAh} \mathrm{g}^{-1}\right)$. The ratio of negative/positive electrodes is optimized based on their irreversible capacities of both $\mathrm{HC}$ and $\mathrm{NaCrO}_{2}$.

Analysis. - Thermal stability was evaluated through thermogravimetric (TG) measurements (STA2500 Regulus, NETZSCH) conducted at a scan rate of $5 \mathrm{~K} \mathrm{~min}^{-1}$. The ionic conductivity was measured by an ac impedance measurement (3532-80 impedance analyzer, Hioki E. E. Corp.) The electrolytes were loaded in a T-shaped poly(tetrafluoroethylene) cell with two stainless steel blocking electrodes in the glove box and placed in a temperature-controlled thermostatic chamber (SU-242, ESPEC). Viscosity was measured using an electromagnetically spinning viscometer EMS-100 (Kyoto Electronics Manufacturing Co., Ltd.). Density was measured by a density meter (DMA 4500M Anton Paar). The electrolytes for density measurements were filled in a $1 \mathrm{~cm}^{3}$ syringe (Terumo SS-01T) with a rubber cap in a glove box and inserted into the density meter without exposing them to air. Cyclic voltammetry (CV) was conducted with a Bio-Logic VSP potentiostat. The potentials of Pt and glass-like carbon (GC) electrodes were swept to $6.0 \mathrm{~V}$ vs. $\mathrm{Na}^{+} / \mathrm{Na}$ to determine the anodic limit. The $\mathrm{Cu}$ electrode potential was swept to $-0.15 \mathrm{~V}$ vs. $\mathrm{Na}^{+} / \mathrm{Na}$ to determine the cathodic limit. The chargedischarge properties of the full cells were measured using 2032 coin-type cells with a chargedischarge unit (HJ1001SD8, Hokuto Denko Corp.). 


\section{Result and Discussion}

\section{Thermal Behavior}

The flammability of the ILOL systems was investigated as photographically illustrated in Figure 1 (details furnished in Table S1, Supplementary Material). Cotton swabs soaked with the ILOL systems with varying IL ratios were exposed to fire (Figure 1a). Predictably, the electrolyte with the highest IL ratio (ILOL 100) completely inhibits flammability, whereas the OL (ILOL 0) was the most flammable of the selected electrolytes (Figure 1b). Correspondingly, ILOL systems with ratios of $\leq 30 \%$ IL were observed to ignite promptly upon exposure to fire, whereas the electrolytes with IL concentrations of $\geq 40 \%$ inhibited flammability. This indicates that increasing the IL concentrations delayed the ignition of the electrolytes. Additionally, the ILOL systems were warmed to $353 \mathrm{~K}$ and exposed to fire to assess their flammability at intermediate temperatures (Figure 1c). Likewise, the ILOL systems with $\geq 40 \%$ IL exhibited suppressed ignition, thus demonstrating their potential to sustain intermediate temperature operations.

To shed light on the thermal stability of the different electrolyte ratios, thermogravimetric measurements were performed on the ILOL systems. As shown in the TG curves in Figure 2, substantial improvements in the thermal stability were noted with increasing ratios of IL. In the OL electrolyte (ILOL 0), a significant weight loss attributed to the evaporation of the PC organic solvent was noted to commence at $333 \mathrm{~K} \cdot{ }^{39-41}$ On the other hand, minimal weight loss was observed below $550 \mathrm{~K}$ in the IL electrolyte (ILOL 100), wherein thermal decomposition occurred at around $600 \mathrm{~K}$. These results suggest that higher IL ratios effectively repress the evaporation of $\mathrm{PC}$, which also provides a plausible explanation for the diminished flammability with increasing IL ratios previously observed. 


\section{Physicochemical Behaviors}

Given the thermal behavior observed, it would be pertinent to understand the influence of temperature on the physicochemical properties of the present hybrid electrolytes. Thus, measurements to ascertain the correlation between the temperature and the ionic conductivity and viscosity of the ILOL systems in comparison with previously studied electrolytes (reference electrolytes) were conducted in the temperature range of $273 \mathrm{~K}$ to $353 \mathrm{~K}$ as summarized in Table 2 and 3, respectively. The Vogel-Tammann-Fulcher (VTF) equations (Eqs. 1 and 2), which are typically applied to fragile systems, ${ }^{42}$ were used to fit the resulting plots shown in Figures 3 and 4, respectively. ${ }^{43-46}$ (see Figures S1 and S2, Supplementary Material, for ionic conductivities and viscosities of the reference electrolytes)

$$
\begin{aligned}
& \sigma(T)=A_{\sigma} T^{-1 / 2} \exp \left(-\frac{B_{\sigma}}{T-T_{0 \sigma}}\right) \\
& \eta(T)=A_{\eta} T^{1 / 2} \exp \left(\frac{B_{\eta}}{T-T_{0} \eta}\right)
\end{aligned}
$$

Here, $\sigma(T)$ and $\eta(T)$ represent the ionic conductivity and viscosity, respectively, as functions of temperature. The $A$ parameter denotes the values at infinite temperature as a constant. The $B$ parameter is a constant depicting the activation energy, and $T_{0}$ indicates the ideal glasstransition temperature.

As reflected in Table 2, the ILOL $0\left(1 \mathrm{~mol} \mathrm{dm}^{-3} \mathrm{Na}\left[\mathrm{ClO}_{4}\right]-\mathrm{PC}\right)$, Ref $1\left(1 \mathrm{~mol} \mathrm{dm}^{-3}\right.$ $\mathrm{Na}$ [FSA]-PC), and Ref $2\left(1 \mathrm{~mol} \mathrm{dm}^{-3} \mathrm{Na}\left[\mathrm{ClO}_{4}+\right.\right.$ FSA]-PC) organic electrolytes exhibit comparable ionic conductivities $\left(6.9,6.3\right.$, and $7.0 \mathrm{mS} \mathrm{cm}^{-1}$, respectively), at $303 \mathrm{~K}$, suggesting that the resident anion species do not have a significant impact on the overall ionic conductivity of these systems (similar observations were also made with ILOL 50 and the Ref 3 electrolytes). 
The data further reveals that increasing the IL concentration initially enhances the ionic conductivity of the electrolyte. However, beyond certain concentrations, the ionic conductivity is seen to deteriorate. For instance, at $303 \mathrm{~K}$, ionic conductivity was improved by increasing the amount of IL, reaching a maximum of $9.7 \mathrm{mS} \mathrm{cm}^{-1}$ at $50 \%$ IL (ILOL 50) but thereafter decreasing to 6.6 and $4.9 \mathrm{mS} \mathrm{cm}^{-1}$ with concentrations of $80 \%$ IL (ILOL 80 ) and $100 \%$ IL (ILOL 100), respectively. These findings conform to the cube-root law, which explicates the correlation between the ionic conductivity and the concentration of the electrolyte (in this case, the concentration was constant to each electrolyte but increasing the amount IL indicate more $\mathrm{C}_{3} \mathrm{C}_{\text {lpyrr }}$ cations and FSA anions). ${ }^{47}$ However, for an interpretation of ionic conductivities at high concentrations, an appropriate theoretical background needs to be applied.

In reference to the viscosity behavior displayed in Table $\mathbf{3}$, increasing the IL ratio engendered more viscous ILOL electrolytes, whereas temperature elevation decreased their viscosity. This suggests that the ionic transport as well as the wettability of the ILOL with porous electrodes (taking into account the role of specific surface interaction) can be improved by elevating the operation temperatures. For further insight, the influence of temperature on the density characteristics and related properties of the ILOL systems compared with the reference electrolytes were also investigated in the temperature range of $278 \mathrm{~K}$ to $363 \mathrm{~K}$ as summarized in Table S2 (Supplementary Material). Figure 5 shows the correlation between the temperature $(T)$ and the densities ( $\rho)$ of the ILOL systems fitted with parameters $A$ and $B$ using Eq. 3 below: (see Figure S3, Supplementary Material, for the densities of reference electrolytes)

$$
\rho=A T+B
$$

The results indicate that increasing the IL concentrations increased the densities of the ILOL 
systems, which were observed to progressively decrease with increasing temperatures. From the densities obtained, the correlation between the temperature and the molar concentrations of the ILOL systems compared to the reference electrolytes in the temperature range of $278 \mathrm{~K}$ to 363 K was calculated, as highlighted in Table S3 (Supplementary Material). Here, the molar concentrations are seen to decrease with increasing temperatures; also concomitant with decreases in the ILOL densities. Typically, lower molar concentrations correspond to high molar conductivity, further affirming the ionic conductivity results previously observed. It should be noted that the molar concentration values remained the same regardless of the type of electrolytes.

\section{Electrochemical Behavior}

In order to determine the electrochemical performance of the ILOL systems, cyclic voltammetry was performed on a three-electrode beaker cell configuration, as shown in Figure 6. Separate anodic scans were carried out using Pt and GC working electrodes along with $\mathrm{Na}$ metal counter and reference electrodes in each case. A Cu working electrode was used for the cathodic scans in the same cell configuration. As exemplified in the combined cyclic voltammograms derived from the ILOL 50 (Figure 6a), the GC and Pt electrodes (threshold: $0.1 \mathrm{~mA} \mathrm{~cm}^{-2}$ ) exhibit anodic limits of $5.7 \mathrm{~V}$ and $5.5 \mathrm{~V}$, respectively (cf. the GC electrode anodic limits of 5.6 V and 5.5 V in the ILOL 0 and ILOL 100 systems, respectively, as shown in Figure 6b). During the cathodic scan and the subsequent anodic scan in the ILOL 50, Na metal deposition and dissolution are observed at $0 \mathrm{~V}$ vs. $\mathrm{Na}^{+} / \mathrm{Na}$ on the $\mathrm{Cu}$ electrode, delivering a high dissolution-deposition Coulombic efficiency of $83 \%$.

For further investigations, galvanostatic assessments of the present ILOL systems were performed using a $\mathrm{HC} / \mathrm{NCO}$ full cell configuration at varying current densities at the temperature of $298 \mathrm{~K}$, as shown in the charge-discharge results and related Ragone plots in 
Figure 7 (see Figures S4 and S5, for the electrochemical data of the HC/NCO full cell using Ref 1, Ref 2, and Ref 3 electrolytes). The charge-discharge curves obtained from the 3 rd cycle of the respective ILOL systems (Figure 7a) clearly indicate the $\mathrm{Cr}(\mathrm{III}) / \mathrm{Cr}(\mathrm{IV}$ ) redox activities occurring within NCO, associated with charge and discharge of the HC/NCO full cells ${ }^{48}$ as well as the reversible $\mathrm{Na}^{+}$insertion/extraction properties of $\mathrm{HC} .{ }^{49}$ Additionally, the $\mathrm{HC} / \mathrm{NCO}$ cells show an average operational voltage of $2.8 \mathrm{~V}$ in the ILOL systems.

Overall, the reversible capacities of the hybrid systems (ILOL) were found to be higher than the OL system ILOL 0, which achieved $66.3 \mathrm{mAhg}^{-1}$ (comparable to Ref1, and Ref2 organic electrolytes) and lower than the IL electrolyte (ILOL 100), which delivered the highest reversible capacity of $78.2 \mathrm{mAhg}^{-1}$. However, among the hybrid electrolytes, the capacity is observed to decrease with increasing the IL concentrations whereby capacities of $71.1 \mathrm{mAh} \mathrm{g}^{-}$ 1, $73.8 \mathrm{mAhg}^{-1}, 74.0 \mathrm{mAhg}^{-1}$ were attained from the ILOL 80, ILOL 50 and ILOL 20, respectively. These observations are consistent with previously reported IL electrolytes for $\mathrm{Na}$ batteries which demonstrated lower irreversible capacities than their OL counterparts. ${ }^{15,21,27,49-}$ 52

Across the various current densities, the ILOL systems demonstrated improved rate capability, as illustrated in Figure 7b. Although the ILOL 100 achieves the highest reversible capacity at $100 \mathrm{~mA} \mathrm{~g}^{-1}$, the ILOL 20 and ILOL 50 attain higher capacity retention at the higher current densities. It is also noted that the dual salt systems comprising $\mathrm{Na}[\mathrm{FSA}]$ and $\mathrm{Na}\left[\mathrm{ClO}_{4}\right]$ yield slightly better rate performance than the single salt systems. For instance, the ILOL 50 system delivers a higher capacity retention than the Ref 3 electrolyte, in a similar manner as the Ref 2 electrolyte, which provides better rate capability than the ILOL 0 and Ref 1 electrolytes (cf. See Table S4 and Figure S4, Supplementary Material). Given the comparable ionic conductivities observed in the dual salt electrolytes (including the hybrid ILOL systems), the improved rate capability attained by ILOL20 and ILOL 50 could be ascribed to the 
formation of a favorable interface that facilitates facile $\mathrm{Na}^{+}$kinetics between the electrode and electrolyte. Nonetheless, a detailed examination of the influence of the dual salt systems on the SEI formation is underway and beyond the scope of the present study.

The correlation between the energy and power densities of the HC/NCO cells utilizing the selected ILOL systems at $298 \mathrm{~K}$ is illustrated by the Ragone plots in Figure 7c. Note that the values were calculated based on the total weight of the HC and NCO. In the ILOL 0 , limited energy densities were observed across all power densities. On the other hand, although ILOL 100 exhibits the highest energy density $\left(158.4 \mathrm{Wh} \mathrm{kg}^{-1}\right)$ at low power density (in this case, 112.6 $\mathrm{W} \mathrm{kg}^{-1}$ ), the energy density significantly declines at higher power densities. Conversely, the ILOL 20 and ILOL 50 hybrid electrolytes were noted to maintain their specific energy densities (125.4 $\mathrm{Wh} \mathrm{kg}^{-1}$ and $125.5 \mathrm{Wh} \mathrm{kg}^{-1}$, respectively) even at high specific power densities (1126.0 $\mathrm{W} \mathrm{kg}-1$ and $1126.7 \mathrm{~W} \mathrm{~kg}^{-1}$ for ILOL 20 and ILOL50, respectively). Thus, the two hybrid electrolytes show adequate capability to deliver a balanced performance across a range of power densities.

The cycle performance of the ILOL systems in a $\mathrm{HC} / \mathrm{NCO}$ full cell configuration was assessed at a current density of $100 \mathrm{~mA} \mathrm{~g}^{-1}$ at the temperature of $298 \mathrm{~K}$, as shown in Figure 8 . A summary of the cycling test results from the ILOL systems is furnished alongside the reference electrolyte systems in Table 4. The capacity provided is based on the weight of NCO. Charge-discharge curves derived from the 1st, 100th, 300th, and 700th cycles (Figure S6) show increased polarization accompanied by decreasing capacity with continued cycling; an indication of cell deterioration with continued cycling. Nevertheless, the ILOL 20 and ILOL 50 hybrid electrolytes display slightly better capacity retention, Coulombic efficiency, and energy efficiency than the non-hybrid systems (ILOL 0 vs. Ref 1 and Ref 2, ILOL 50 vs. Ref 3). Moreover, at the 700th cycle, the two electrolytes (ILOL 20 and ILOL 50) deliver high capacity retention ( $\sim 55 \%$ ) and high average Coulombic efficiencies (above $99 \%$ ), comparable 
to the previously studied electrolytes (Ref 1, 2, and 3). In fact, the ILOL 50 achieves the highest energy efficiency of $95.4 \%$ at the 700 th cycle among the tested electrolytes, suggesting the improved performance of the ILOL system.

Throughout the present study, ILOL 50 has displayed remarkable electrochemical performance at $298 \mathrm{~K}$ (Figure 8) as well as favorable thermal properties such as lack of flammability even at intermediate temperatures of $353 \mathrm{~K}$ (see Table S1, Supplementary Material). This prompted further investigation into the cyclic performance of this hybrid electrolyte (ILOL 50) in a $\mathrm{HC} / \mathrm{NCO}$ full cell configuration at the intermediate temperature of $363 \mathrm{~K}$. The cell was cycled for 500 cycles at a current density of $100 \mathrm{~mA} \mathrm{~g}^{-1}$ in the voltage range of 3.5 1.4 V. The capacity provided is based on the weight of NCO. As shown in Figure 9, the ILOL 50 manifests a stable cycle performance at $363 \mathrm{~K}$. Although a slightly higher capacity $\left(79.5 \mathrm{mAh} \mathrm{g}^{-1}\right)$ is achieved at $363 \mathrm{~K}$ compared to cycling at $298 \mathrm{~K}$, a faster capacity degradation is noted to occur at the elevated temperature. This is attributed to the enhanced electrolyte degradation triggered by the temperature increase, thus leading to higher consumption of the electrolytes with the progressing cycles. Nonetheless, reasonably high capacity retention values of $62.5 \%$ and $48.4 \%$ are obtained after 200 cycles and 500 cycles, respectively. These results evince that the ILOL 50 system as an electrolyte contender for the development of intermediate-temperature SIBs. 


\section{Conclusions}

This study presents a group of hybrid electrolytes as an auspicious avenue not only for reducing the cost but also to deliver high performance and improved safety for SIBs. Herein, we note that the flammability of the organic electrolytes was effectively suppressed by adding the amount of IL into the system. Moreover, the presence of IL in the organic electrolyte (OL) (equivalently OL in the IL) significantly enhanced ionic conductivity, achieving a maximum ionic conductivity of $8.4 \mathrm{mS} \mathrm{cm}-1$ at $298 \mathrm{~K}$ (ILOL 50). Compared to the conventional OL and IL electrolytes, the ILOL systems in $\mathrm{HC} / \mathrm{NCO}$ full cell configurations showed improved rate capability and stable performance at $298 \mathrm{~K}$, achieving the highest Coulombic and energy efficiencies with the ILOL 50. In addition, the ILOL 50 facilitated full-cell performance at an elevated temperature of $363 \mathrm{~K}$, evincing its suitability for intermediate-temperature SIBs. This study affirms the ILOL 50 hybrid electrolyte as a two-prolonged solution for the cost and safety issues presently hampering SIB practicality. Further exploration into the solvation structure and interfacial properties (SEI layer) formed by the different ratios of IL and OL will be the subject of future studies.

\section{Acknowledgements}

This study was partly supported by the Japanese Ministry of Education, Culture, Sports, Science and Technology (MEXT) program "Elements Strategy Initiative to Form Core Research Center" (JPMXP0112101003). 
Table 1. Abbreviations and compositions of the ILOL and reference electrolytes.

\begin{tabular}{|c|c|}
\hline Abbreviation & Electrolytes \\
\hline ILOL $0^{*}$ & $1 \mathrm{~mol} \mathrm{dm}^{-3} \mathrm{Na}[\mathrm{FSA}]-\left[\mathrm{C}_{3} \mathrm{C}_{1}\right.$ pyrr][FSA] $+1 \mathrm{~mol} \mathrm{dm}^{-3} \mathrm{Na}\left[\mathrm{ClO}_{4}\right]-\mathrm{PC}(0: 10, \mathrm{v}: \mathrm{v})$ \\
\hline ILOL 10 & $1 \mathrm{~mol} \mathrm{dm}^{-3} \mathrm{Na}[\mathrm{FSA}]-\left[\mathrm{C}_{3} \mathrm{C}_{1}\right.$ pyrr] $]$ FSA $]+1 \mathrm{~mol} \mathrm{dm}^{-3} \mathrm{Na}\left[\mathrm{ClO}_{4}\right]-\mathrm{PC}(1: 9, \mathrm{v}: \mathrm{v})$ \\
\hline ILOL 20 & $1 \mathrm{~mol} \mathrm{dm}^{-3} \mathrm{Na}[\mathrm{FSA}]-\left[\mathrm{C}_{3} \mathrm{C}_{1}\right.$ pyrr][FSA] $+1 \mathrm{~mol} \mathrm{dm}^{-3} \mathrm{Na}\left[\mathrm{ClO}_{4}\right]-\mathrm{PC}(2: 8, \mathrm{v}: \mathrm{v})$ \\
\hline ILOL 30 & $1 \mathrm{~mol} \mathrm{dm}^{-3} \mathrm{Na}[\mathrm{FSA}]-\left[\mathrm{C}_{3} \mathrm{C}_{1}\right.$ pyrr $][\mathrm{FSA}]+1 \mathrm{~mol} \mathrm{dm}^{-3} \mathrm{Na}\left[\mathrm{ClO}_{4}\right]-\mathrm{PC}(3: 7, \mathrm{v}: \mathrm{v})$ \\
\hline ILOL 40 & $1 \mathrm{~mol} \mathrm{dm}^{-3} \mathrm{Na}[\mathrm{FSA}]-\left[\mathrm{C}_{3} \mathrm{C}_{1}\right.$ pyrr] $[\mathrm{FSA}]+1 \mathrm{~mol} \mathrm{dm}^{-3} \mathrm{Na}\left[\mathrm{ClO}_{4}\right]-\mathrm{PC}(4: 6, \mathrm{v}: \mathrm{v})$ \\
\hline ILOL 50 & $1 \mathrm{~mol} \mathrm{dm}^{-3} \mathrm{Na}[\mathrm{FSA}]-\left[\mathrm{C}_{3} \mathrm{C}_{1}\right.$ pyrr][FSA] $+1 \mathrm{~mol} \mathrm{dm}^{-3} \mathrm{Na}\left[\mathrm{ClO}_{4}\right]-\mathrm{PC}(5: 5, \mathrm{v}: \mathrm{v})$ \\
\hline ILOL 60 & $1 \mathrm{~mol} \mathrm{dm}^{-3} \mathrm{Na}[\mathrm{FSA}]-\left[\mathrm{C}_{3} \mathrm{C}_{1}\right.$ pyrr $][\mathrm{FSA}]+1 \mathrm{~mol} \mathrm{dm}^{-3} \mathrm{Na}\left[\mathrm{ClO}_{4}\right]-\mathrm{PC}(6: 4, \mathrm{v}: \mathrm{v})$ \\
\hline ILOL 70 & $1 \mathrm{~mol} \mathrm{dm}^{-3} \mathrm{Na}[\mathrm{FSA}]-\left[\mathrm{C}_{3} \mathrm{C}_{1}\right.$ pyrr] $][\mathrm{FSA}]+1 \mathrm{~mol} \mathrm{dm}^{-3} \mathrm{Na}\left[\mathrm{ClO}_{4}\right]-\mathrm{PC}(7: 3, \mathrm{v}: \mathrm{v})$ \\
\hline ILOL 80 & $1 \mathrm{~mol} \mathrm{dm}^{-3} \mathrm{Na}[\mathrm{FSA}]-\left[\mathrm{C}_{3} \mathrm{C}_{1}\right.$ pyrr $][\mathrm{FSA}]+1 \mathrm{~mol} \mathrm{dm}^{-3} \mathrm{Na}\left[\mathrm{ClO}_{4}\right]-\mathrm{PC}(8: 2, \mathrm{v}: \mathrm{v})$ \\
\hline ILOL 90 & $1 \mathrm{~mol} \mathrm{dm}^{-3} \mathrm{Na}[\mathrm{FSA}]-\left[\mathrm{C}_{3} \mathrm{C}_{1}\right.$ pyrr][FSA $]+1 \mathrm{~mol} \mathrm{dm}^{-3} \mathrm{Na}\left[\mathrm{ClO}_{4}\right]-\mathrm{PC}(9: 1, \mathrm{v}: \mathrm{v})$ \\
\hline ILOL $100 * *$ & $1 \mathrm{~mol} \mathrm{dm}^{-3} \mathrm{Na}[\mathrm{FSA}]-\left[\mathrm{C}_{3} \mathrm{C}_{1}\right.$ pyrr] $][\mathrm{FSA}]+1 \mathrm{~mol} \mathrm{dm}^{-3} \mathrm{Na}\left[\mathrm{ClO}_{4}\right]-\mathrm{PC}(10: 0, \mathrm{v}: \mathrm{v})$ \\
\hline Ref 1 & $1 \mathrm{~mol} \mathrm{dm}^{-3} \mathrm{Na}[\mathrm{FSA}]-\mathrm{PC}$ \\
\hline $\operatorname{Ref} 2$ & $1 \mathrm{~mol} \mathrm{dm}^{-3} \mathrm{Na}\left[\mathrm{ClO}_{4}+\mathrm{FSA}\right]-\mathrm{PC}$ \\
\hline Ref 3 & $1 \mathrm{~mol} \mathrm{dm}{ }^{-3} \mathrm{Na}[\mathrm{FSA}]-\left[\mathrm{C}_{3} \mathrm{C}_{1}\right.$ pyrr $][\mathrm{FSA}]+\mathrm{PC}(5: 5, \mathrm{v}: \mathrm{v})$ \\
\hline \multicolumn{2}{|c|}{$\begin{array}{l}* 1 \mathrm{~mol} \mathrm{dm}^{-3} \mathrm{Na}\left[\mathrm{ClO}_{4}\right]-\mathrm{PC} \\
* * 1 \mathrm{~mol} \mathrm{dm}^{-3} \mathrm{Na}[\mathrm{FSA}]\left[\mathrm{C}_{3} \mathrm{C}_{1} \text { pyrr }\right][\mathrm{FSA}]\end{array}$} \\
\hline
\end{tabular}


Table 2. Ionic conductivity results $\left(\mathrm{mS} \mathrm{cm}^{-1}\right)$ and the VTF fitting parameters for the ILOL and reference electrolytes.

\begin{tabular}{|c|c|c|c|c|c|c|c|c|}
\hline \multirow{2}{*}{$\begin{array}{l}\text { Temp. } \\
\text { / K }\end{array}$} & \multicolumn{8}{|c|}{ Electrolytes } \\
\hline & ILOL 0 & ILOL 20 & ILOL 50 & ILOL 80 & ILOL 100 & Ref 1 & Ref 2 & Ref 3 \\
\hline 273 & 2.9 & 3.6 & 3.2 & 1.8 & 1.2 & 2.4 & 3.0 & 3.0 \\
\hline 283 & 4.2 & 5.2 & 4.9 & 3.0 & 2.2 & 3.6 & 4.2 & 4.7 \\
\hline 293 & 5.5 & 7.1 & 7.1 & 4.6 & 3.4 & 4.9 & 5.6 & 6.9 \\
\hline 303 & 6.9 & 9.3 & 9.7 & 6.6 & 5.0 & 6.3 & 7.0 & 9.5 \\
\hline 313 & 8.5 & 11.7 & 12.6 & 9.0 & 7.0 & 8.0 & 8.7 & 12.4 \\
\hline 323 & 10.0 & 14.4 & 15.9 & 11.8 & 9.3 & 9.6 & 10.4 & 15.8 \\
\hline 333 & 12.1 & 17.1 & 19.4 & 14.8 & 12.3 & 11.5 & 12.2 & 19.3 \\
\hline 343 & 13.6 & 20.1 & 23.2 & 18.3 & 15.3 & 13.4 & 14.3 & 23.5 \\
\hline 353 & 15.2 & 23.0 & 27.2 & 21.9 & 19.1 & 15.1 & 16.2 & 27.6 \\
\hline $\begin{array}{l}A_{\sigma} / \mathrm{mS} \\
\mathrm{cm}^{-1} \mathrm{~K}^{1 / 2}\end{array}$ & 117 & 254 & 422 & 502 & 948 & 121 & 158 & 498 \\
\hline$B_{\sigma} / \mathrm{K}$ & 363 & 440 & 501 & 564 & 763 & 352 & 428 & 534 \\
\hline$T_{0 \sigma} / \mathrm{K}$ & 175 & 170 & 170 & 173 & 158 & 183 & 165 & 168 \\
\hline
\end{tabular}


Table 3. Viscosity results $(\mathrm{mPa} s)$ and the VTF fitting parameters for the ILOL and $\mathrm{r}$ eference electrolytes.

\begin{tabular}{|c|c|c|c|c|c|c|c|c|}
\hline \multirow{2}{*}{$\begin{array}{c}\text { Temp. } \\
\text { / K }\end{array}$} & \multicolumn{8}{|c|}{ Electrolytes } \\
\hline & ILOL 0 & ILOL 20 & ILOL 50 & ILOL 80 & ILOL 100 & Ref 1 & Ref 2 & Ref 3 \\
\hline 273 & 15.4 & 22.9 & 54.5 & 158.0 & 320.4 & 15.4 & 15.5 & 17.1 \\
\hline 283 & 10.6 & 15.3 & 33.7 & 93.0 & 183.6 & 10.8 & 10.6 & 11.2 \\
\hline 293 & 7.7 & 10.9 & 23.2 & 58.7 & 114.0 & 7.8 & 7.7 & 7.7 \\
\hline 303 & 5.8 & 8.0 & 16.0 & 39.4 & 74.8 & 5.9 & 5.8 & 5.9 \\
\hline 313 & 4.6 & 6.2 & 11.7 & 27.7 & 51.8 & 4.6 & 4.4 & 4.5 \\
\hline 323 & 3.6 & 4.8 & 8.8 & 20.4 & 37.4 & 3.8 & 3.6 & 3.8 \\
\hline 333 & 2.9 & 3.9 & 7.0 & 15.6 & 27.9 & 3.2 & 2.9 & 3.3 \\
\hline 343 & 2.5 & 3.2 & 5.6 & 12.2 & 21.4 & 2.8 & 2.5 & 2.7 \\
\hline 353 & 2.1 & 2.7 & 4.6 & 9.8 & 16.9 & 2.5 & 2.2 & 2.4 \\
\hline $\begin{array}{c}10^{2} \times A_{\eta} \\
/ \mathrm{mS} \mathrm{cm} \\
-1 \mathrm{~K}^{1 / 2}\end{array}$ & 7 & 7.5 & 8.9 & 13.3 & 16.0 & 17.7 & 10.2 & 32.0 \\
\hline$B_{\eta} / \mathrm{K}$ & 730 & 762 & 815 & 870 & 963 & 492 & 610 & 324 \\
\hline$T_{0 \eta} / \mathrm{K}$ & 137 & 140 & 146 & 150 & 146 & 163 & 151 & 191 \\
\hline
\end{tabular}


Table 4. Summary of cycle test results obtained from HC/NCO full cells utilizing the ILOL and reference electrolytes. ${ }^{a}$

\begin{tabular}{ccccccc}
\hline Electrolytes & $\begin{array}{l}\text { Capacity } \\
\text { retention (1st } \\
\text { vs. 300th } \\
\text { cycle 1\%) }\end{array}$ & $\begin{array}{l}\text { Average } \\
\text { C.E. (300 } \\
\text { cycles /\%) }\end{array}$ & $\begin{array}{l}\text { Average } \\
\text { E.E. (300 } \\
\text { cycle 1\%) }\end{array}$ & $\begin{array}{l}\text { Capacity } \\
\text { retention (1st } \\
\text { vs. 700th } \\
\text { cycle /\%) }\end{array}$ & $\begin{array}{l}\text { Average C.E. } \\
(700 \text { cycles } \\
1 \%)\end{array}$ & $\begin{array}{l}\text { Average E.E. } \\
(700 \text { cycles } \\
1 \%)\end{array}$ \\
\hline ILOL 0 & 63.9 & 99.6 & 94.9 & 39.9 & 99.6 & 93.7 \\
ILOL 20 & 75.7 & 99.6 & 95.7 & 54.7 & 99.6 & 95.3 \\
ILOL 50 & 74.2 & 99.7 & 95.7 & 55.3 & 99.7 & 95.4 \\
ILOL 80 & 70.8 & 99.6 & 94.2 & 50.7 & 99.6 & 93.8 \\
ILOL 100 & 72.3 & 99.8 & 94.3 & 52.8 & 99.9 & 93.9 \\
Ref 1 & 73.1 & 99.5 & 94.6 & 55.0 & 99.5 & 94.1 \\
Ref 2 & 75.7 & 99.6 & 95.1 & 56.4 & 99.7 & 94.6 \\
Ref 3 & 73.2 & 99.9 & 95.2 & 55.6 & 99.7 & 93.0 \\
\hline a C.E. and E.E. denote Coulombic and energy efficiencies, respectively. \\
\hline \multicolumn{7}{c}{}
\end{tabular}


(a)

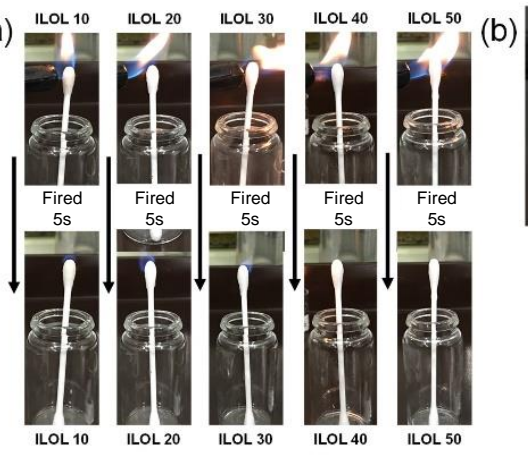

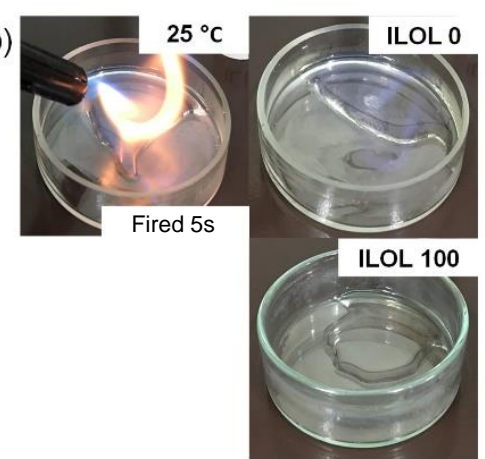

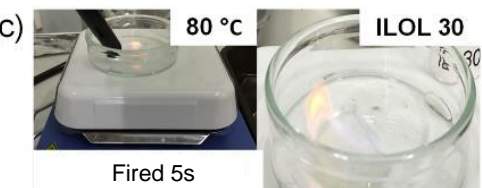

Fired $5 s$

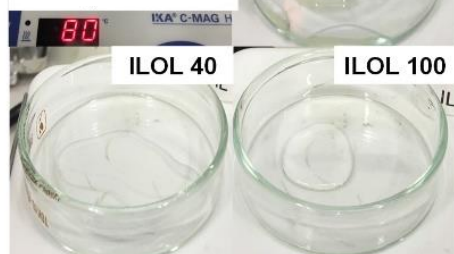

Figure 1. Summary of flammability tests for the ILOL systems. (a) Cotton swabs soaked with electrolytes exposed to fire. Electrolytes in Petri dishes (b) at $298 \mathrm{~K}$ and (c) at $353 \mathrm{~K}$. See Table S1, Supplementary Material, for a summary of the ILOL system flammability tests. 


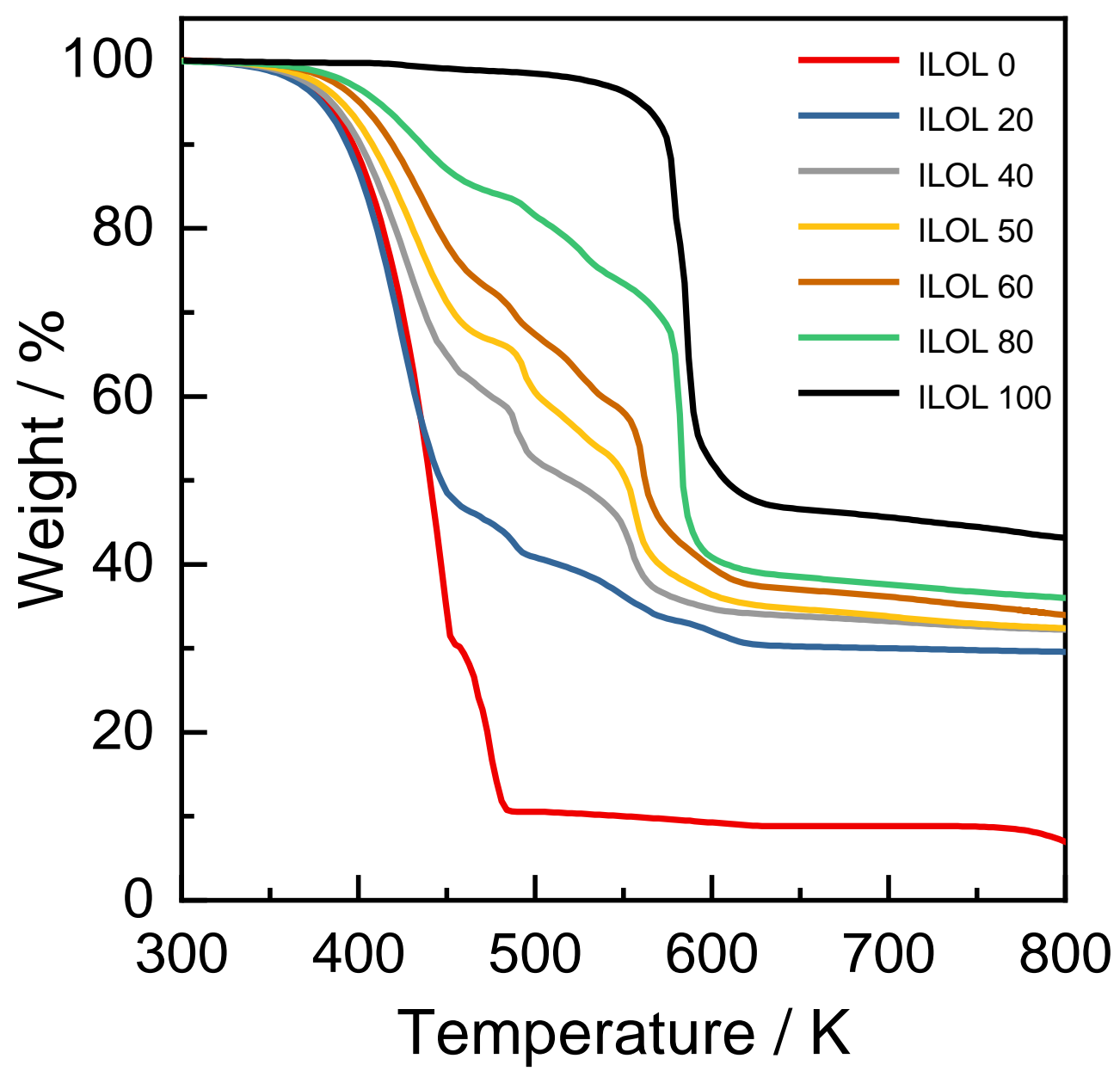

Figure 2. TG curves of the ILOL systems measured at a scan rate of $5 \mathrm{~K} \mathrm{~min}^{-1}$ under Ar atmosphere. 


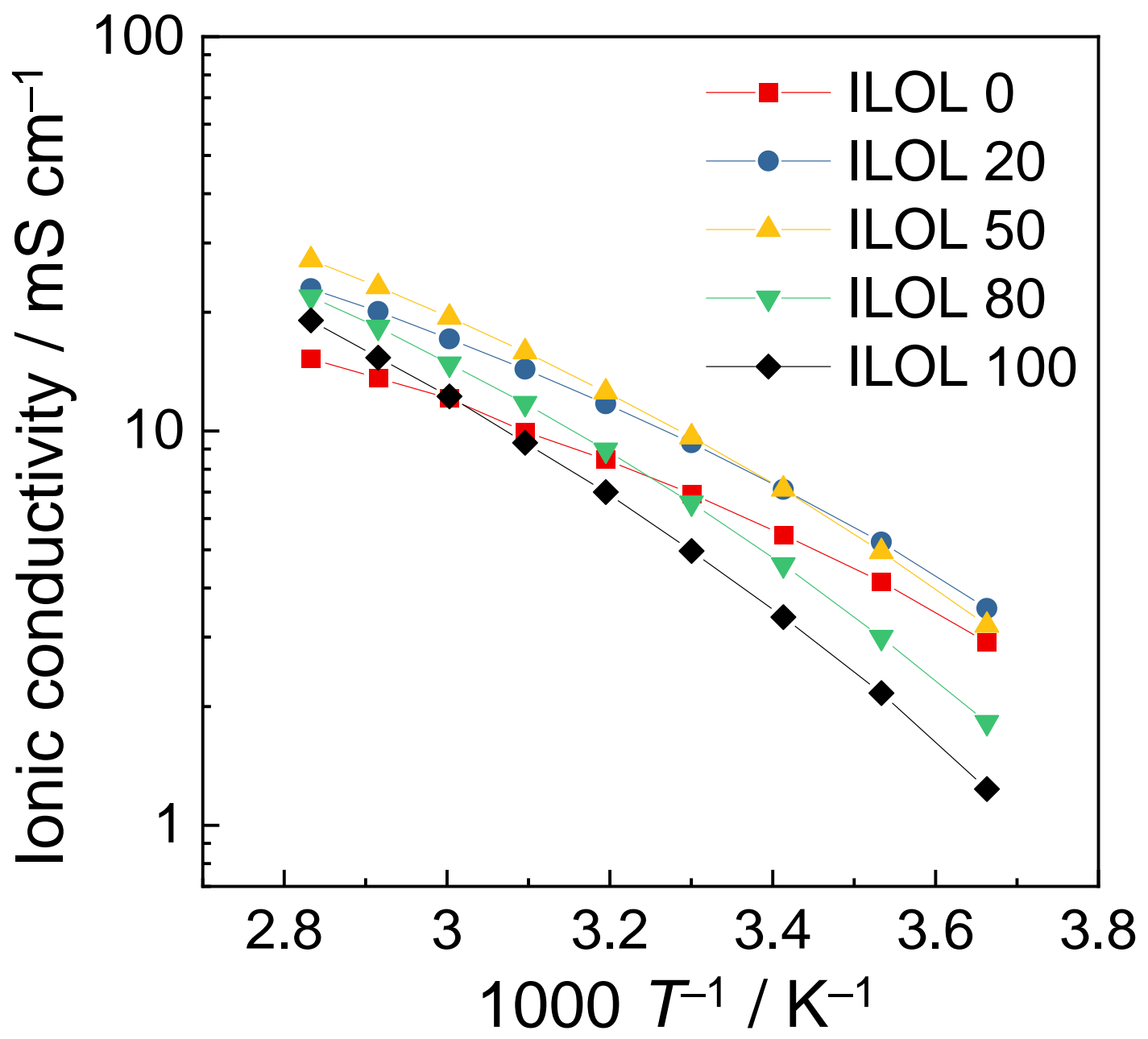

Figure 3. Temperature dependence of ionic conductivity of the ILOL systems. See Figure S1, Supplementary Material, for the ionic conductivity results from the reference electrolytes and Table 2 for a summary of the ionic conductivity results and VTF fitting parameters. 


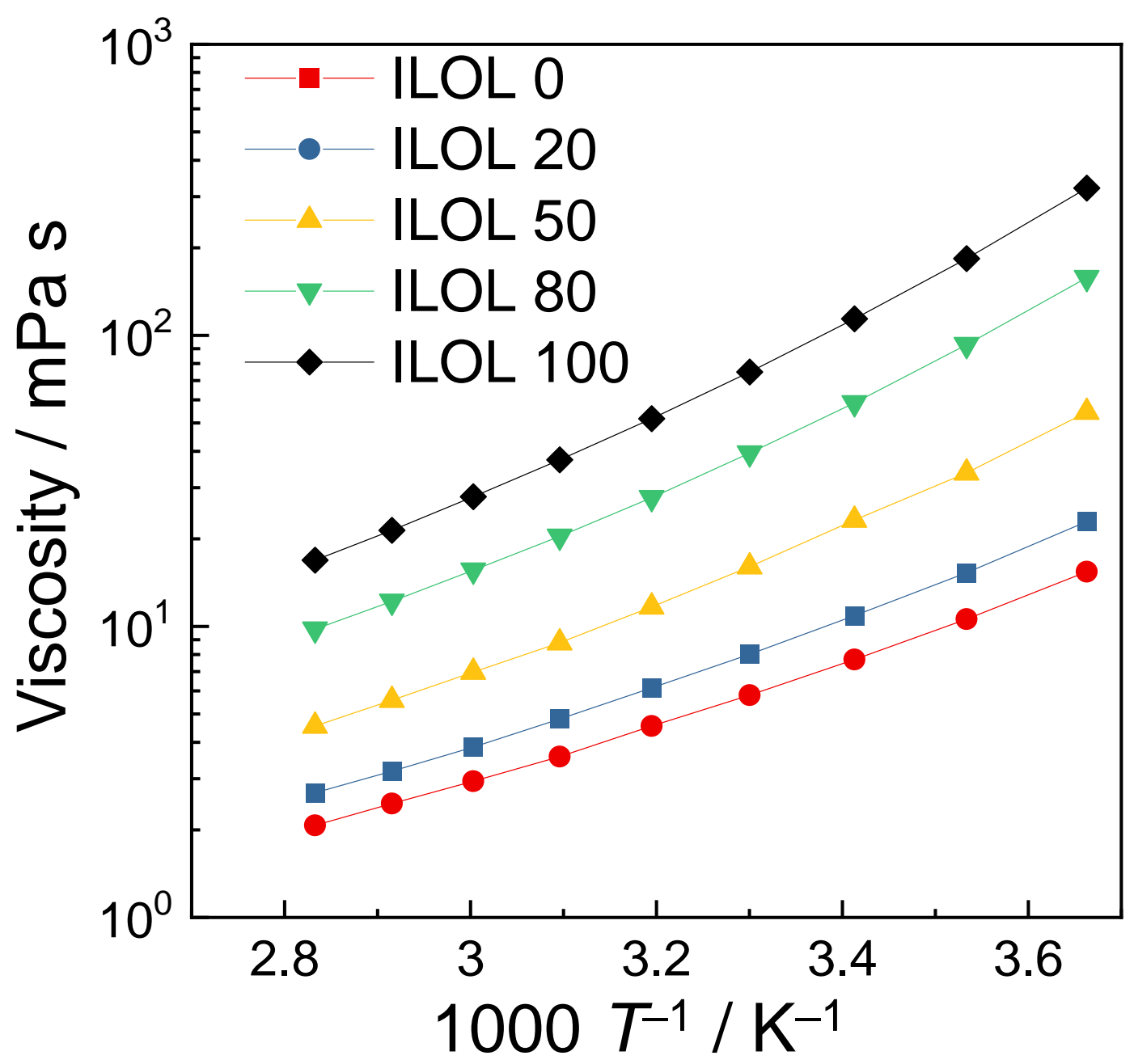

Figure 4. Temperature dependence of viscosity of the ILOL systems. See Figure S2, Supplementary Material, for the viscosity results from the reference electrolytes and Table 3 for a summary of the viscosity results and VTF fitting parameters. 


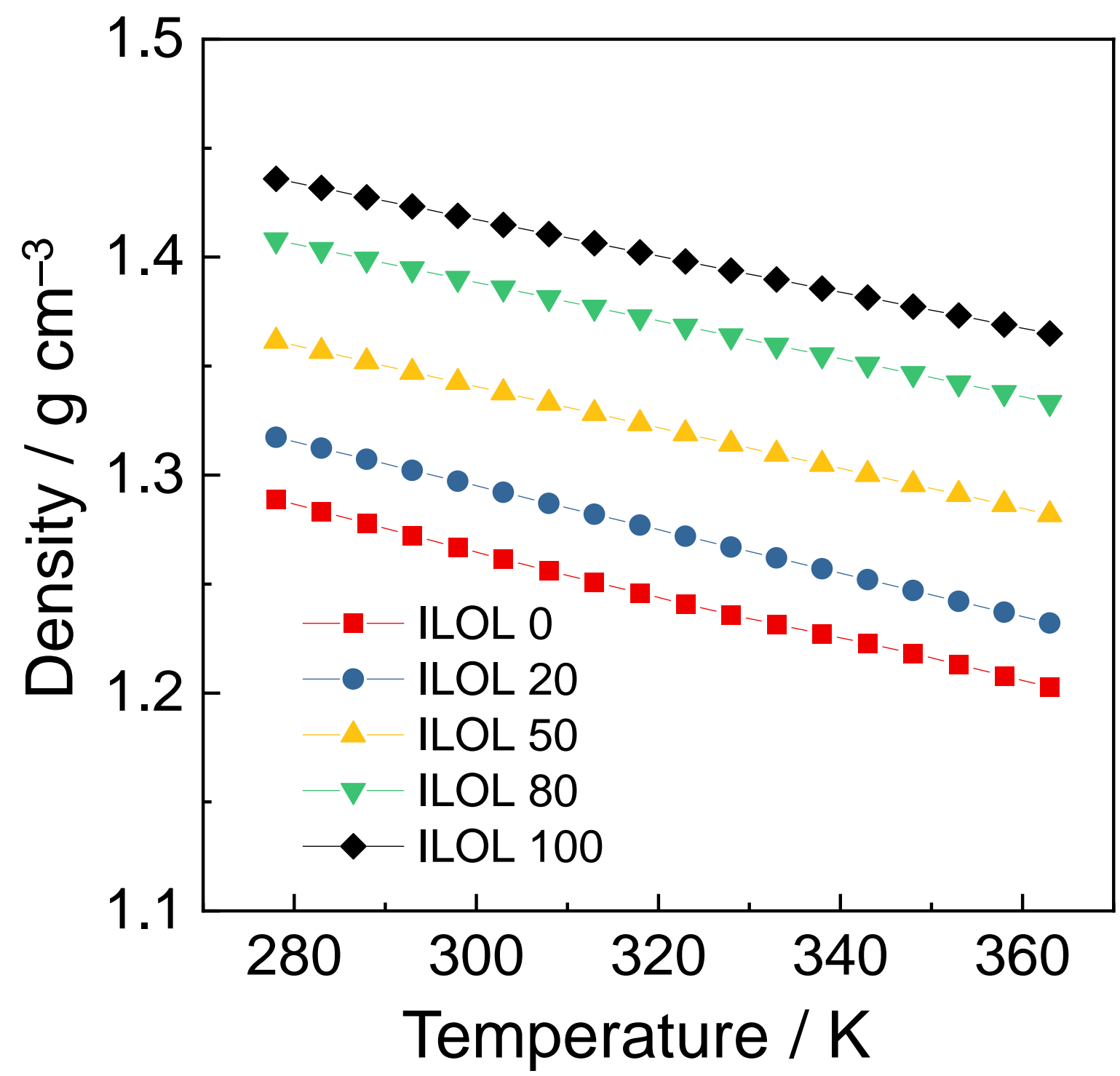

Figure 5. Temperature dependence of densities for the ILOL systems. See Figure S3, Supplementary Material, for the densities of the reference electrolytes and Table S2, Supplementary Material, for a summary of the densities and fitting parameters. 

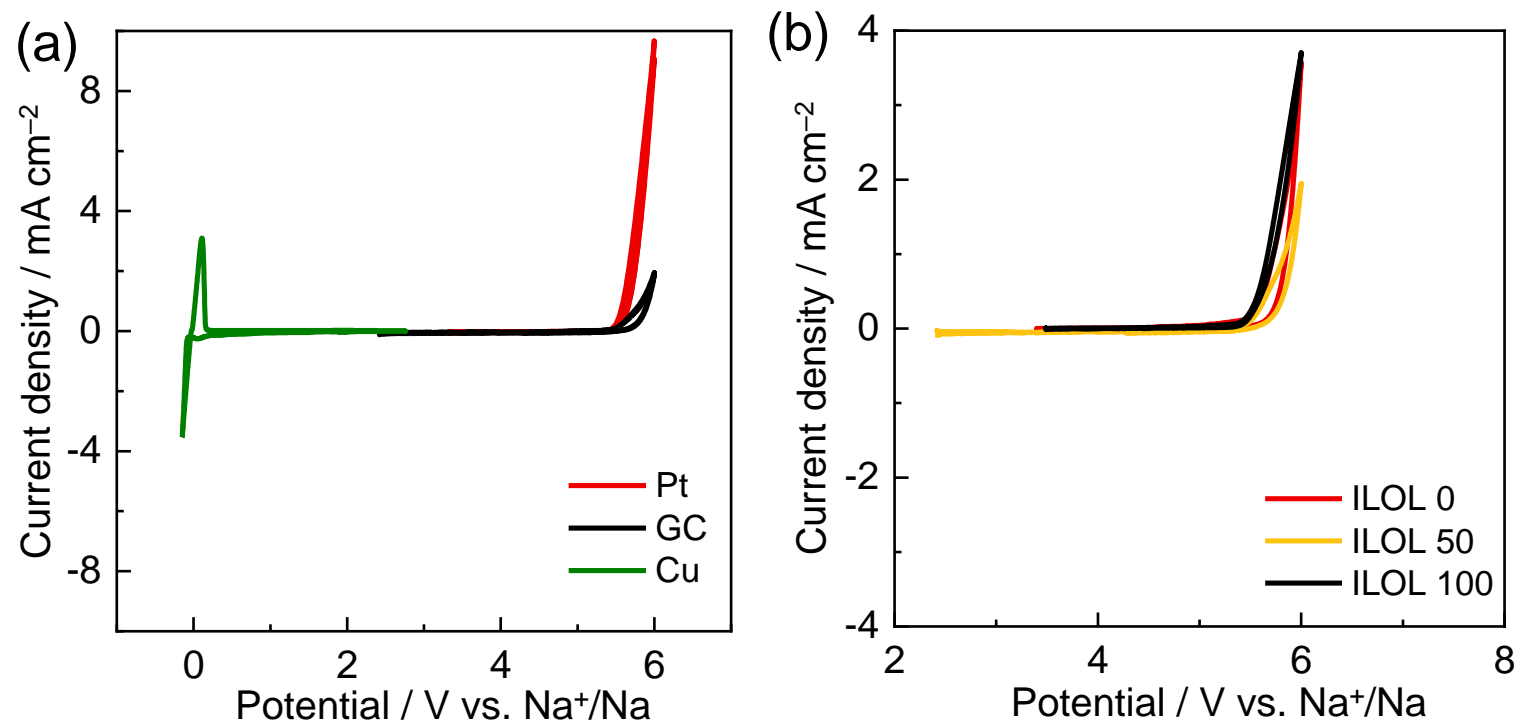

Figure 6. Cyclic voltammograms of the ILOL systems at 298 K. (a) Anodic and cathodic scans with the Pt, GC, and $\mathrm{Cu}$ electrodes in ILOL 50 and (b) anodic scans with the GC electrode in ILOL 0, the ILOL 50, and the ILOL 100. 

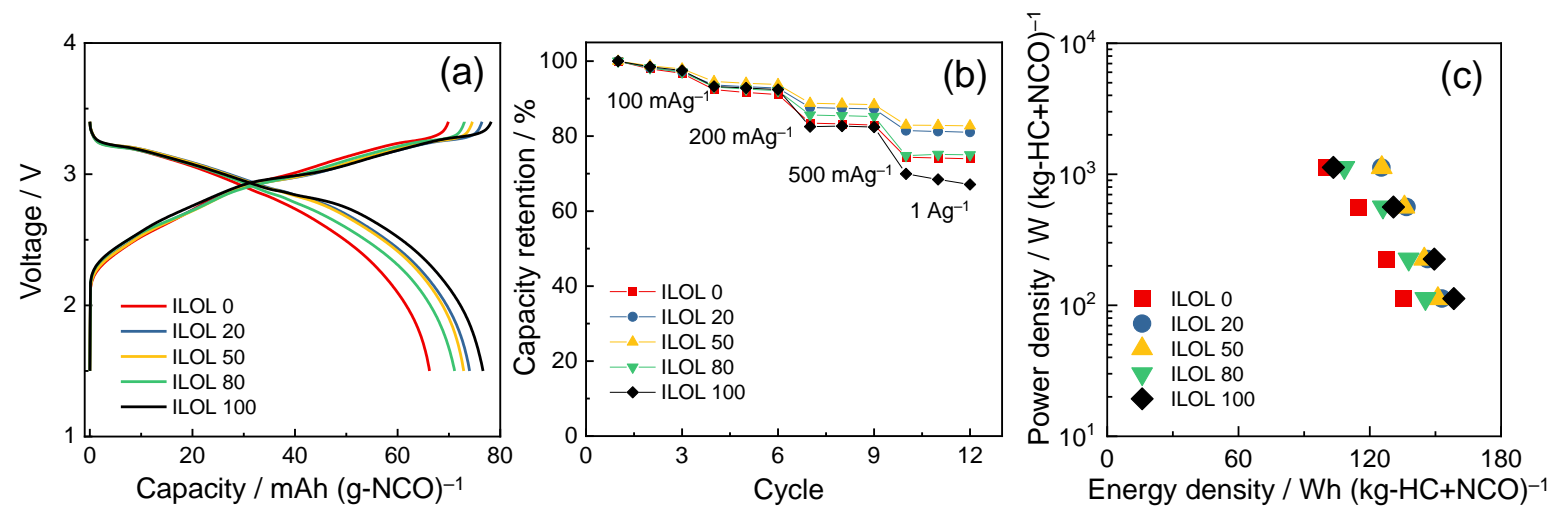

Figure 7. Electrochemical properties of the HC/NCO full cells comprising the ILOL systems at 298 K. (a) Charge-discharge curves of the 3rd cycle, (b) rate capability, and (c) Ragone Plots. Power and energy densities are calculated based on the sum of HC and NCO weights. Temperature: $298 \mathrm{~K}$. 

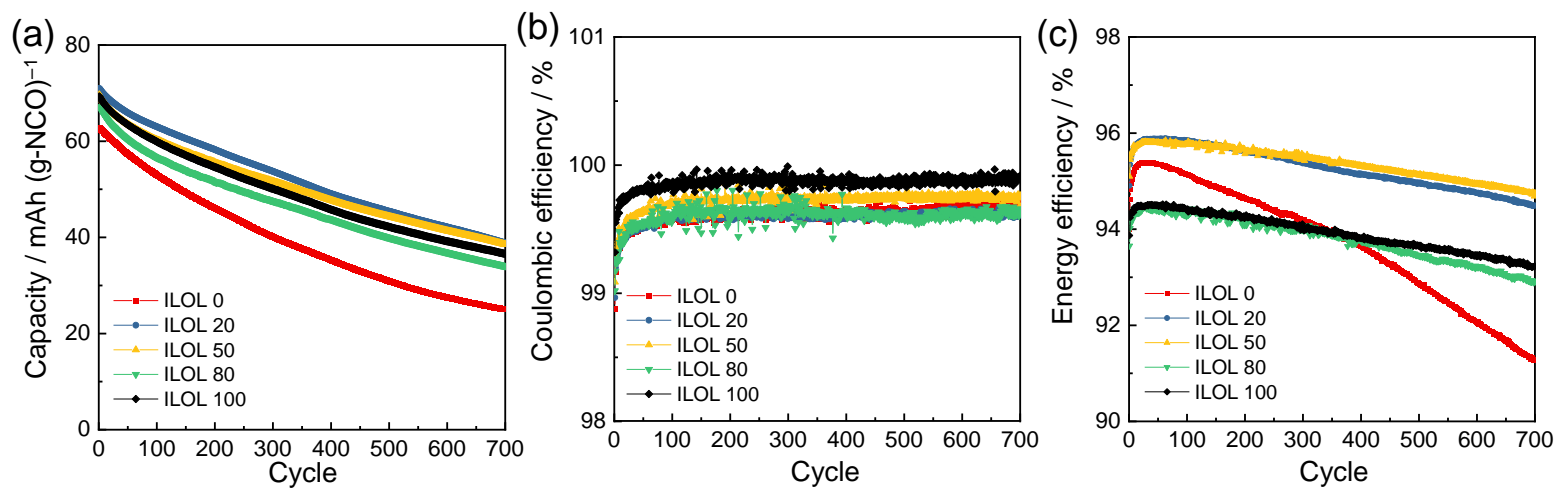

Figure 8. Cycle performance of the HC/NCO full cells with the ILOL systems at $298 \mathrm{~K}$. Cutoff voltage $=3.5-1.4 \mathrm{~V}$ and current density $=100 \mathrm{~mA} \mathrm{~g}^{-1}$. Capacity is based on the weight of NCO. (See Figure S5 in Supplementary Material for cycle tests of the HC/NCO full cells with the reference electrolytes) 


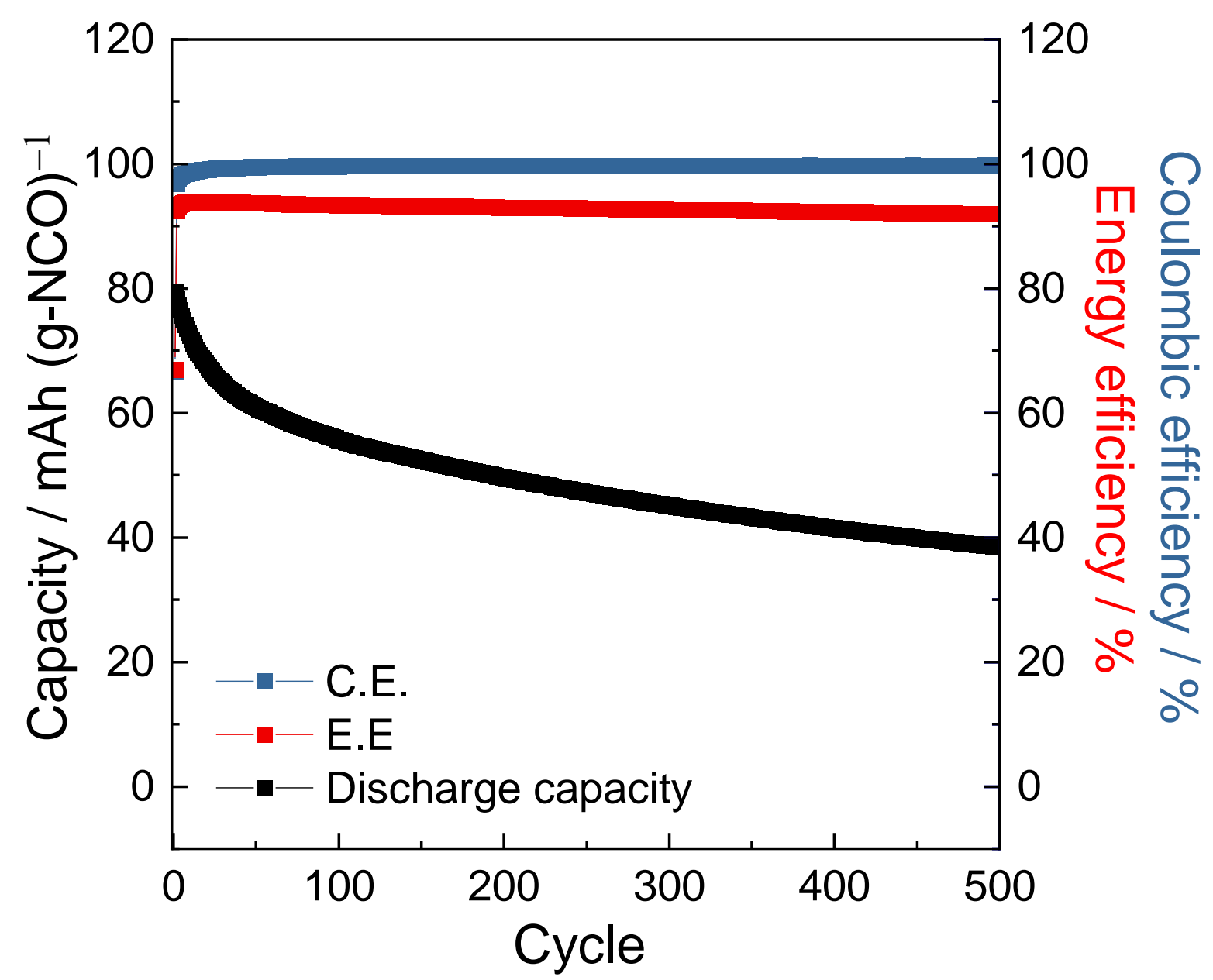

Figure 9. Cycle performance of the HC/NCO full cell with ILOL 50 at $363 \mathrm{~K}$. Cutoff voltage $=3.5-1.4 \mathrm{~V}$ and current density $=100 \mathrm{~mA} \mathrm{~g}^{-1}$. Capacity is based on the weight of NCO. 


\section{Acknowledgments}

J. H. is grateful to the Japan Society for the Promotion of Science (JSPS) for the Grant-in-Aid for Scientific Research Fellowship. This study was partly supported by the Grant-in-Aid for Scientific Research grant program (19J14235) and the Japanese Ministry of Education, Culture, Sports, Science, and Technology (MEXT) program "Elements Strategy Initiative to Form Core Research Center" (JPMXP0112101003).

\section{ORCID}

Jinkwang Hwang: 0000-0003-4800-3158

Huan Yang: 0000-0002-8757-5733

Kazuhiko Matsumoto: 0000-0002-0770-9210

Rika Hagiwara: 0000-0002-7234-3980

\section{References}

1. N. Yabuuchi, K. Kubota, M. Dahbi, S. Komaba, Chem. Rev., 114, 11636 (2014).

2. S.-W. Kim, D.-H. Seo, X. Ma, G. Ceder, K. Kang, Adv. Energy Mater., 2, 710 (2012).

3. J.-M. Tarascon, Nat. Chem., 2, 510 (2010).

4. M. D. Slater, D. Kim, E. Lee, C. S. Johnson, Adv. Funct. Mater., 23, 947 (2013).

5. G. Yan, D. Alves-Dalla-Corte, W. Yin, N. Madern, G. Gachot, J.-M. Tarascon, J. Electrochem. Soc., 165, A1222 (2018).

6. G. A. Giffin, J. Mater. Chem. A, 4, 13378 (2016).

7. A. Ponrouch, D. Monti, A. Boschin, B. Steen, P. Johansson, M. R. Palacin, J. Mater. Chem. A, 3, 22 (2015).

8. H. Che, S. Chen, Y. Xie, H. Wang, K. Amine, X.-Z. Liao, Z.-F. Ma, Energy Environ. Sci., 10, 1075 (2017).

9. G. C. Yan, K. Reeves, D. Foix, Z. J. Li, C. Cometto, S. Mariyappan, M. Salanne, J. M. Tarascon, Adv. Energy Mater., 9, 1901431 (2019).

10. A. Ponrouch, E. Marchante, M. Courty, J.-M. Tarascon, M. R. Palacín, Energy Environ. Sci., 5, 8572 (2012).

11. G. Åvall, J. Mindemark, D. Brandell, P. Johansson, Adv. Energy Mater., 8, 1703036 (2018). 12. T. Minato, H. Kawaura, M. Hirayama, S. Taminato, K. Suzuki, N. L. Yamada, H. Sugaya, K. Yamamoto, K. Nakanishi, Y. Orikasa, H. Tanida, R. Kanno, H. Arai, Y. Uchimoto, Z. Ogumi, J. Phys. Chem. C, 120, 20082 (2016).

13. D. Takamatsu, Y. Orikasa, S. Mori, T. Nakatsutsumi, K. Yamamoto, Y. Koyama, T. Minato, T. Hirano, H. Tanida, H. Arai, Y. Uchimoto, Z. Ogumi, J. Phys. Chem. C, 119, 9791 (2015). 
14. A. Basile, M. Hilder, F. Makhlooghiazad, C. Pozo-Gonzalo, D. R. MacFarlane, P. C. Howlett, M. Forsyth, Adv. Energy Mater., 8, 1703491 (2018).

15. K. Matsumoto, J. Hwang, S. Kaushik, C.-Y. Chen, R. Hagiwara, Energy Environ. Sci., 12, 3247 (2019).

16. K. Matsumoto, T. Hosokawa, T. Nohira, R. Hagiwara, A. Fukunaga, K. Numata, E. Itani, S. Sakai, K. Nitta, S. Inazawa, J. Power Sources, 265, 36 (2014).

17. K. Matsumoto, Y. Okamoto, T. Nohira, R. Hagiwara, J. Phys. Chem. C, 119, 7648 (2015). 18. H. Sun, G. Zhu, X. Xu, M. Liao, Y.-Y. Li, M. Angell, M. Gu, Y. Zhu, W. H. Hung, J. Li, Y. Kuang, Y. Meng, M.-C. Lin, H. Peng, H. Dai, Nat. Commun., 10, 3302 (2019).

19. C.-H. Wang, C.-H. Yang, J.-K. Chang, Chem. Commun., 52, 10890 (2016).

20. D. M. Fox, W. H. Awad, J. W. Gilman, P. H. Maupin, H. C. De Long, P. C. Trulove, Green Chemistry, 5, 724 (2003).

21. J. Hwang, K. Takeuchi, K. Matsumoto, R. Hagiwara, J. Mater. Chem. A, 7, 27057 (2019). 22. G. H. Lane, P. M. Bayley, B. R. Clare, A. S. Best, D. R. MacFarlane, M. Forsyth, A. F. Hollenkamp, J. Phys. Chem. C, 114, 21775 (2010).

23. H. Yoon, A. S. Best, M. Forsyth, D. R. MacFarlane, P. C. Howlett, Phys. Chem. Chem. Phys., 17, 4656 (2015).

24. S. Kaushik, J. Hwang, K. Matsumoto, Y. Sato, R. Hagiwara, ChemElectroChem, 5, 1337 (2018).

25. J. Hwang, K. Matsumoto, R. Hagiwara, Adv. Energy Mater., 10, 2001880 (2020).

26. J. Hwang, K. Matsumoto, R. Hagiwara, Adv. Sustainable Syst., 2, 1700171 (2018).

27. X.-F. Luo, W.-H. Chiang, C.-Y. Su, T.-Y. Wu, S. B. Majumder, J.-K. Chang, ACS Sustain. Chem. Eng., 7, 16682 (2019).

28. J. Hwang, K. Matsumoto, R. Hagiwara, ACS Appl. Energy Mater., 2, 2818 (2019).

29. A. Guerfi, M. Dontigny, P. Charest, M. Petitclerc, M. Lagace, A. Vijh, K. Zaghib, J. Power Sources, 195, 845 (2010).

30. R. S. Kuehnel, N. Boeckenfeld, S. Passerini, M. Winter, A. Balducci, Electrochim. Acta, 56, 4092 (2011).

31. H. Li, J. Pang, Y. Yin, W. Zhuang, H. Wang, C. Zhai, S. Lu, RSC Adv., 3, 13907 (2013).

32. J. Patra, C.-H. Wang, T.-C. Lee, N. Wongittharom, Y.-C. Lin, G. Ting-Kuo Fey, S. B. Majumder, C.-T. Hsieh, J.-K. Chang, RSC Adv., 5, 106824 (2015).

33. S. Theivaprakasam, D. R. MacFarlane, S. Mitra, Electrochim. Acta, 180, 737 (2015).

34. C. Arbizzani, G. Gabrielli, M. Mastragostino, J. Power Sources, 196, 4801 (2011).

35. D. Monti, A. Ponrouch, M. R. Palacin, P. Johansson, J. Power Sources, 324, 712 (2016).

36. L. M. T. Le, T. D. Vo, Q. D. Nguyen, S. Okada, F. Alloin, P. L. M. Le, ECS Trans., 85, 215 (2018).

37. C. V. Manohar, A. Raj K, M. Kar, M. Forsyth, D. R. MacFarlane, S. Mitra, Sustain. Energy Fuels, 2, 566 (2018).

38. C.-Y. Chen, K. Matsumoto, T. Nohira, R. Hagiwara, A. Fukunaga, S. Sakai, K. Nitta, S. Inazawa, J. Power Sources, 237, 52 (2013).

39. F. Wu, N. Zhu, Y. Bai, Y. Li, Z. Wang, Q. Ni, H. Wang, C. Wu, Nano Energy, 51, 524 (2018).

40. F. Wu, N. Zhu, Y. Bai, L. Liu, H. Zhou, C. Wu, ACS Appl. Mater. Interfaces, 8, 21381 (2016).

41. K. Xu, Chem. Rev., 104, 4303 (2004).

42. W. Xu, E. I. Cooper, C. A. Angell, J. Phys. Chem. C, 107, 6170 (2003).

43. K. Matsumoto, R. Taniki, T. Nohira, R. Hagiwara, J. Electrochem. Soc., 162, A1409 (2015).

44. H. Vogel, Phys. Z., 22, 645 (1921). 
45. G. Tammann, W. Hesse, Z. Anorg. Allg. Chem., 156, 245 (1926).

46. G. S. Fulcher, J. Am. Ceram. Soc., 8, 339 (1925).

47. J. E. Desnoyers, B. E. Conway, J. Phys. Chem. C, 68, 2305 (1964).

48. C.-Y. Yu, J.-S. Park, H.-G. Jung, K.-Y. Chung, D. Aurbach, Y.-K. Sun, S.-T. Myung, Energy Environ. Sci., 8, 2019 (2015).

49. S. Komaba, W. Murata, T. Ishikawa, N. Yabuuchi, T. Ozeki, T. Nakayama, A. Ogata, K. Gotoh, K. Fujiwara, Adv. Funct. Mater., 21, 3859 (2011).

50. D. I. Iermakova, R. Dugas, M. R. Palacín, A. Ponrouch, J. Electrochem. Soc. , 162, A7060 (2015).

51. J. Patra, H.-T. Huang, W. Xue, C. Wang, A. S. Helal, J. Li, J.-K. Chang, Energy Storage Mater., 16, 146 (2019).

52. G. G. Eshetu, S. Grugeon, H. Kim, S. Jeong, L. Wu, G. Gachot, S. Laruelle, M. Armand, S. Passerini, ChemSusChem, 9, 462 (2016). 
